\title{
American Race Relations and THE LegaCy OF BRITISH ColonialisM
}

\author{
Written by Thomas H. Stanton \\ (New York and Oxon: Routledge, 2020) \\ ISBN: 9780367423216
}

\section{Kuangran Li* \& Wei Shen**}

\begin{abstract}
British colonial policies have led to stratified societies all over the world and America is no exception. But America is unique in transiting to an equal society and constructing the legal framework to achieve a fair society, even though not completely successful. What distinguishes America from other British colonies is the tradition of rule of law. Perhaps this tradition is also the most priceless heritage that the Britain left for America. Currently, racial discrimination and racial equality protests spread across America. This book provides valuable insights for understanding the divided America.
\end{abstract}

\section{Keywords}

Race, British Colonialism, Rule of Law, US Constitution, Divided Society

Race relations is one of the societal and legal issues troubling the US from time to time. The recent "Black Life Matters" movement is a manifest example showing the severity and complexity of the race relations in the US. Against this backdrop, Thomas H. Stanton in his book, American Race Relations AND tHe Legacy of BrITISH ColOnIALISM, timely rolls out a historic landscape of the US race issue.

* Ph.D. candidate, Shanghai Jiao Tong University Law School. LL.B. (ECUPL), LL.M. (McGill), LL.M. (Boston U.). He may be contacted at: kr.lee@sjtu.edu.cn.

** KoGuan Distinguished Professor of Law at Shanghai Jiao Tong University Law School. LL.B. \& LL.M. (ECUPL), LL.M. (Michigan), LL.M. (Cantab), Ph.D. (LSE). ORCID: https://orcid.org/0000-0002-6935-1365?lang=en. He may be contacted at: shenwei@sjtu.edu.cn /Address: 1954 Huashan Road Shanghai 200030 P.R. China. 
This is a concise book with five chapters analyzing the root of racial divisions in America. It illuminates with numerous cases, laws and regulations, and examples of colonies in other continents. The critical term in this book is "rule of law," which distinguishes this book from other writings on the same subject. This book clarifies the interplay between rule of law and a divided society, and explains the reasons that America managed to become united. The author tries to explain that even though America has not totally escaped from the bogs of remaining divided but the process is much shorter and the level of united is stronger than other British colonies-and became the most powerful country in the world.

Chapter 1 presents a brief introduction on the effects of British colonial rule to the American society. Despite the distortion the British colonial rule tainted on the American society just like other countries' colonial rules, perhaps the most precious legacy the Britain left for the American is the ideal of rule of law. However, this legacy did not cure the divided American society, which was distorted by factors of slavery, rule by law and others, until the World War II. This book highly praised the rule of law as follows:

The rule of law came into play as the key instrument for deconstructing the divided society in America. ... the fact that the United States had a rule of law meant that social division could be addressed by including people of all races in those whom the rule of law benefited. ${ }^{1}$

The rule of law tradition prevented the American society from retrogressing to colonial period. However, the wind of social division could still be traced in contents of particular laws, court decisions, and implementation of laws.

Chapter 2-"Colonial Economies, Societies, and Laws"-introduces, in the first section, the economic incentives for British Empire to govern American colonies, which was to use the colonies to "provide raw materials and help to reduce British dependence on foreign sources of supply." ${ }^{2}$ However, this approach aroused American ire because this approach was recognized as to actually cut off the trade of America with the rest of the world. The economic incentives also stimulated the slave trade, setting the scene for future social division. While the British Empire was no longer willing to pay considerable administration fees for colonies, economic control was a better ruling method, which was later defined as 'neocolonialism.' The second section moves to the impact of British colonial rule on a divided American society. 
To accurately depict the society at that time, the book adopts the idea of "plural society" proposed by John S. Furnivall. ${ }^{3}$ In a plural society, all types of "racial and ethnic groups who were thrown together in the colonial enterprise and who find little

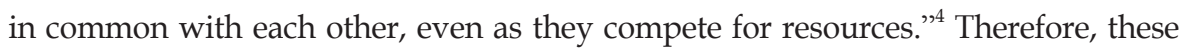
racial and ethnic groups had no motivation to merge or integrate into a unity, even though they lived in the same country for years. The impact of plural society lasted to the post-colonial era when imported minorities were expelled or pressured to leave America, as a result of the lack of political cohesion in a plural society.

Chapter 3 delves into the idea of rule of law and its social influence. This chapter consists of four sections. The first two sections explain the idea of rule of law in depth. The third section is a literature review of different meanings of rule of law. The last section concerns the rule of law in the US Constitution. To fully understand the term of rule of law, this chapter first compares the idea of rule of law with rule by law, highlighting the major difference between these concepts, that is, "between law that seeks to hold even the powerful accountable and law as an instrument of authoritarian rule." ${ }^{, 5}$ In the American colonies (and other British colonies, such as India and Hong Kong), it is interestingly noted that rule of law and rule by law coexisted on the same land at the same period, with rule of law applied to white settlers and rule by law applied to imported slaves. The co-existence of both principles not only exacerbated the division among racial and ethnic groups, but also contributed to the American Revolution. According to Professor Tom R. Tyler,

... the legal system of a colonial plural society can be considered to consist of a rule of law that is seen as legitimate by those on top but may be felt as sheer injustice by those at the bottom... In the colonial context, at least for the favored white settler population, the law became an instrument to shape a plural society and assert dominance within it. ${ }^{6}$

This book contends that it is the tradition of rule of law that helps America to outstand other British colonies and to wipe off the injustices of the plural society and slavery system. The ultimate purpose of rule of law, according to Albert V. Dicey, is to limit the power of government through "a set of procedural safeguards of the

3 Id. at 9, recited from J. Furnivall, Colonial policy and practice: A comparative study of Burma and Netherlands INDia 309 (1956).

$4 \quad$ Id. at 12.

$5 \quad$ Id. at 16.

6 Id. at 20, recited from T. Tyler, Why People Obey The Law (1990). 
courts that protect freedoms against arbitrary violation."7 Edward P. Thompson concluded that law not only reflects the interests of the ruling class, but also protects the lower class against arbitrary violation. ${ }^{8}$

After admitting the significance of rule of law, an interesting question may arise how America deeply embedded the idea of rule of law in people's mind. In other words, how to cultivate the consciousness to be bound by law and governed by law. Therefore, the last section focuses on the US Constitution. Lawrence Friedman praised the US Constitution's contribution to the stability of the country which could not be ignored or denied. The book emphasizes three characteristics of the US Constitution: (1) the process of judicial review, which helps the Constitution not to be "merely a set of lofty aspirations"; (2) inclusiveness and possibilities to evolve, so as to adapt to unforeseen conditions; and (3) administrative capacity, which guarantees rule of law effectively implemented. Through the Constitution, these legal traditions and rule of law get reinforced in people's mind, and the idea of rule of law adds greater openness and inclusiveness to the regime legitimacy and provides a solid ground for implementing laws. The author then concludes that "it is appropriate to examine the role of law in defining American society from colonial times to the present and to explore how the rule of law has helped American society to come to where it is today.",

The focus of Chapter 4 concerns law in a divided society like the US. It introduces the changing history of law and protection set by legal decisions towards black slaves. This chapter starts with a list of American laws and cases which extended colonial rules of distinguishing white settlers from black slaves. Even in the Constitution, though it avoided the word "slavery," the intentions to protect interests of slave states could still be inferred from several provisions. These intentions could be deemed as a compromise of the Constitution framers to unite the Northern states and Southern states after the Revolutionary War. With economic changes and increasing usage of wage labor in Northern states, the slavery system was finally abolished by law and cases after the Civil War. As mentioned in Chapter 1, however, the restrictions on slaves still remained in the American society divided which was not fundamentally changed by the end of the World War II. The book concludes that the World War II, the fight against extreme racism in Nazi Germany, the Cold War, and nonviolent resistance philosophy (from Gandhi) had a (positive) effect on attacking racism in America, respectively. All these factors and others led to the legislation of the Civil

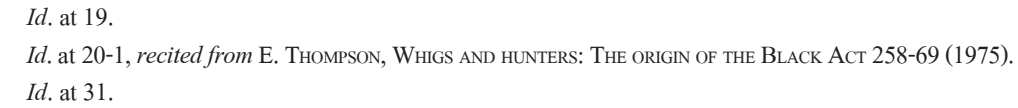


Rights Act of 1964 and the Voting Rights Act of 1965, which were the impressive achievements for the integration of the American society. Further, it evidently proves that "the legal framework of the divided society has been largely dismantled."10 However, this is not the end but another starting point. The chapter concludes that:

both poor implementation of the act and the limited remedies that authorities sought under the act meant that its effects were more modest than they might have been... the focus of many has shifted to overcoming the patterns of behavior that the legal framework has shaped. ${ }^{11}$

Throughout the history, the American society has made great effort to "digest" the legacy of colonial divided society, thereby making substantial progresses. Yet, the society remained divided and stratified. The protests of "Black Lives Matter" has not faded away in all minds. Last chapter proposes that the solution to deepen the level of united and ease the tension between different races is to develop positive interracial relationships and civic networks. Certainly, this will not work out without rule of law.

This book is a valuable addition to the large amount of legal literature on rule of law and race. In a refined way of expression, it marries the analysis of race discrimination left by British colonial rules with the rule of law, a potential cure to the American society which is still divided. It is recommended for those who seek to understand the history of racial conflict in America from the syncretic of society, politics and law. Its value lies in a historical account of rule of law in a changing society. We are in juncture at this moment witnessing some populism movements domestically and globally. The best way to encounter these uncertain changes is to strengthen rule of law, calling for politicians and law professionals' attention to cultivating and reinforcing the idea (or ideal) of rule of law. 
